\author{
JOURNAL OF MANAGEMENT OF AQUATIC RESOURCES. \\ Volume, Nomor, Tahun 2012, Halaman 1-7 \\ Online di : http://ejournal-s1.undip.ac.id/index.php/maquares
}

\title{
KERAPATAN DAN DISTRIBUSI LAMUN (SEAGRASS) BERDASARKAN ZONA KEGIATAN YANG BERBEDA DI PERAIRAN PULAU PRAMUKA, KEPULAUAN SERIBU
}

\author{
Fiki Feryatun, Boedi Hendrarto, Niniek Widyorini *)
}

Jurusan Perikanan, Fakultas Perikanan dan Ilmu Kelautan, Universitas Diponegoro

Jl. Prof. H. Soedharto, SH, Tembalang Semarang 50275 Telp/Fax (024) 7474698

\begin{abstract}
Abstrak
Lamun merupakan tumbuhan yang beradaptasi penuh untuk dapat hidup di lingkungan laut. Ekosistem lamun berperan penting di wilayah pesisir karena menjadi habitat penting untuk berbagai jenis hewan laut seperti ikan, moluska, crustacea, echinodermata. Penelitian yang dilakukan pada bulan April 2012 di Perairan Pantai Pulau Pramuka bertujuan untuk mengetahui komunitas lamun (jenis, kelimpahan, penutupan) dan distribusinya di berbagai zona di Perairan Pantai Pulau Pramuka, Kepulauan Seribu. Sampling dilakukan di tiga stasiun, yakni stasiun 1 (zona alami), stasiun 2 (zona pemukiman) dan stasiun 3 (zona resort wisatawan) menggunakan kuadran transek. Hasil yang didapatkan 7 jenis lamun yaitu Cymodocea rotundata, Cymodocea serrulata, Enhalus acoroides, Halodule uninervis, Halophila ovalis, Thalassia hemprichii dan Syringodium isoetifolium. Kerapatan lamun yang tertinggi diperoleh di stasiun 1 yaitu 1.620 individu/15 $\mathrm{m}^{2}$. Berdasarkan Keputusan Menteri Negara Lingkungan Hidup No. 20 Tahun 2004 bahwa stasiun 1 (zona alami) dengan persentase penutupan 68\% masuk kedalam kondisi sehat (penutupan $\geq 60 \%$ ), sedangkan untuk stasiun 2 (zona pemukiman) dan 3 (zona resort) dengan persentase masing-masing 59\% dan 48\% masuk dalam kategori kondisi kurang sehat (penutupan 30-59,9\%). Pola sebaran (distribusi) lamun pada stasiun 1 mengelompok (cluster) dan seragam (uniform) untuk stasiun 2 dan 3, dengan demikian ada pengaruh dari kegiatan manusia terhadap komunitas lamun.
\end{abstract}

Kata kunci : Lamun, Kerapatan dan Distribusi, Zona kegiatan

\begin{abstract}
Seagrasses are plants adapted to live fully in the marine environment. Seagrass plays an important role in coastal areas due to critical habitat for many kinds of marine animals such as fish, mollusks, crustaceans, echinoderms. The research was conducted on April 9 to 22, 2012 at Pramuka Island Coastal Waters in order to know seagrass community (type, abundance, coverage) distribution in different activity zones. The method used transect quadrates in three stations, namely stations 1 (natural zone), station 2 (residential zone) and station 3 (tourist resort zone). The results obtained 7 seagrass species that was of Cymodocea rotundata, Cymodocea serrulata, Enhalus acoroides, Halodule uninervis, Halophila ovalis, Thalassia hemprichii and Syringodium isoetifolium. The highest seagrass density was in station 1 the total 1620 individuals $/ 15 \mathrm{~m}^{2}$. Based on the Ministry of Environment No. 20 In 2004 the station 1 (natural zone) was in healthy condition (coverage $\geq 60 \%$ ), while for station 2 (residential zone) and 3 (resort zone) were in the category of unhealthy conditions (coverage 30 to 59,9\%). The pattern of distribution of seagrass at stations 1 was clumped, however distribution it was cluster at station 2 and 3, thus there is the influence of human activities on seagrass communities.
\end{abstract}

Keywords : Seagrass, Density and Distribution, Activity zones

\section{Pendahuluan}

Lamun merupakan suatu ekosistem yang sangat penting dalam wilayah pesisir karena memiliki keanekaragaman hayati tinggi, sebagai habitat yang baik bagi beberapa biota laut (spawning, nursery dan feeding ground) dan merupakan ekosistem yang tinggi produktivitas organiknya (Nontji, 2002). Berkembangnya kegiatan manusia di wilayah pesisir khususnya di perairan pantai Pulau Pramuka seperti kegiatan pariwisata, pemukiman, dan aktivitas lainnya memungkinkan adanya pengaruh terhadap ekosistem lamun, sehingga diduga mengalami perubahan fisik,

*) Penulis Penanggung Jawab 


\section{JOURNAL OF MANAGEMENT OF AQUATIC RESOURCES. \\ Volume, Nomor, Tahun 2012, Halaman 1-7 \\ Online di : http://ejournal-s1.undip.ac.id/index.php/maquares}

kelimpahan maupun sebarannya. Kiswara (2000) menulis bahwa hilangnya lamun secara luas telah terjadi di berbagai tempat di belahan dunia sebagai akibat dari dampak langsung kegiatan manusia termasuk kerusakan secara mekanis (pengerukan), pengaruh pembangunan konstruksi pesisir. Dikhawatirkan hilangnya padang lamun ini akan terus meningkat akibat berkembangnya kegiatan manusia di daerah pesisir. Untuk itu perlu dilakukan penelitian khususnya mengenai kelimpahan dan distribusi lamun. Tujuan dari penelitian yang dilaksanakan pada tanggal 9 - 22 April 2012 ini adalah untuk mengetahui jenis-jenis lamun yang ditemui, kelimpahan/kerapatan dan penutupan, serta mengetahui distribusi (pola sebaran) lamun pada zona kegiatan yang berbeda.

\section{Materi dan Metode Penelitian}

\section{A. Materi Penelitian}

Materi yang digunakan dalam penelitian ini yaitu lamun di Perairan Pantai Pulau Pramuka, Kawasan Seksi Pengelolaan Taman Nasional III Kepulauan Seribu. Variabel yang diamati terdiri dari variabel utama (jenis-jenis lamun, persen penutupan, kerapatan, distribusi) dan variabel penunjang (suhu, arus, salinitas, substrat, $\mathrm{pH}$ ).

\section{B. Metode Penelitian}

Metode yang digunakan adalah metode observasi langsung bersifat studi kasus (Gulo, 2005). Penentuan lokasi sampling dibagi menjadi tiga stasiun dimana setiap stasiun dibagi lagi menjadi tiga substasiun, berdasarkan pada perbedaan karakteristik lokasi tiap stasiun yaitu sebelah utara, timur dan selatan. Tiga stasiun yang mewakili zona kegiatan adalah stasiun 1 (zona alami) di sebelah utara, stasiun 2 (zona pemukiman) di sebelah timur dan stasiun 3 (zona resort wisatawan) di wilayah selatan. Pengamatan tidak dilakukan di bagian barat karena menjadi kawasan dermaga sehingga pada lokasi tersebut kurang dari $15 \mathrm{~m}$ ke arah pantai sudah terdapat tubir. Data didapatkan dengan melakukan sampling di tiap stasiun dengan peletakkan kuadran transek sebagai bidang pengamatan. Jenis-jenis lamun yang ditemui dicocokkan dengan melihat referensi identifikasi lamun menurut Field Guide to the Identification of East Asian WESTPAC (2010). Setelah data-data didapat, kemudian dilakukan pengolahan data yang terdiri dari kerapatan; persentase penutupan; frekuensi, Indeks Morisita (Brower et al., 1989), uji korelasi dengan bantuan Microsoft Excel 2007.

\section{Hasil dan Pembahasan}

Penelitian ini bertujuan untuk mengetahui komunitas lamun (jenis, kerapatan, penutupan) dan distribusinya di berbagai zona di Perairan Pantai Pulau Pramuka, Kepulauan Seribu.

\section{Jenis-jenis Lamun}

Jenis-jenis lamun yang ditemukan di ketiga stasiun disajikan pada Tabel 1.

Tabel 1. Jenis-jenis Lamun yang Ditemukan di Masing-masing Stasiun

\begin{tabular}{clccc}
\hline No & \multicolumn{1}{c}{ Jenis } & Stasiun 1 & Stasiun 2 & Stasiun 3 \\
\hline 1 & Cymodocea rotundata & $\sqrt{ }$ & $\sqrt{ }$ & $\sqrt{ }$ \\
2 & Cymodocea serrulata & $\sqrt{ }$ & $\sqrt{ }$ & - \\
3 & Enhalus acoroides & $\sqrt{ }$ & $\sqrt{ }$ & $\sqrt{ }$ \\
4 & Halodule uninervis & $\sqrt{ }$ & - & - \\
5 & Halophila ovalis & $\sqrt{ }$ & - & - \\
6 & Thalassia hemprichii & $\sqrt{ }$ & $\sqrt{ }$ & $\sqrt{ }$ \\
7 & Syringodium isoetifolium & $\sqrt{ }$ & - & $\sqrt{ }$ \\
\hline
\end{tabular}

Dalam Tabel 1 dapat dilihat stasiun 1 (alami) memiliki jenis lamun yang paling banyak diantara kedua stasiun lainnya. Tujuh jenis lamun ditemukan pada stasiun 1, sedangkan stasiun 2 dan 3 hanya ditemukan 4 jenis saja. Jenis lamun yang mendominasi dan tersebar merata di tiap stasiun yakni Cymodocea rotundata, Enhalus acoroides dan Thalassia hemprichii sedangkan yang paling rendah sebarannya yakni Halodule uninervis dan Halophila ovalis karena hanya terdapat pada stasiun 1 .

\section{Kerapatan Lamun}

Kerapatan spesies lamun adalah banyaknya jumlah individu/tegakan suatu spesies lamun pada luasan tertentu. Hasil yang diperoleh dapat dilihat sebagai berikut dalam Tabel 2.

Tabel 2. Kerapatan Jenis (Di) dan Kerapatan Relatif (RDi) (ind/15m²)

\begin{tabular}{clcccccc}
\hline \multirow{2}{*}{ No } & \multirow{2}{*}{ Jenis } & \multicolumn{2}{c}{ Stasiun 1 } & \multicolumn{2}{c}{ Stasiun 2 } & \multicolumn{2}{c}{ Stasiun 3 } \\
\cline { 3 - 7 } & & $\mathrm{Di}$ & $\mathrm{RDi}$ & $\mathrm{Di}$ & $\mathrm{RDi}$ & $\mathrm{Di}$ & $\mathrm{RDi}$ \\
\hline 1 & Cymodocea rotundata & 589 & 36,4 & 533 & 36,3 & 395 & 33,8 \\
2 & Cymodocea serrulata & 43 & 2,6 & 26 & 1,8 & - & - \\
3 & Enhalus acoroides & 260 & 16 & 222 & 15,1 & 82 & 7 \\
4 & Halodule uninervis & 21 & 1,3 & - & - & - & - \\
5 & Halophila ovalis & 45 & 2,8 & - & - & - & - \\
\hline
\end{tabular}

${ }^{*}$ Penulis Penanggung Jawab 
JOURNAL OF MANAGEMENT OF AQUATIC RESOURCES.

Volume, Nomor, Tahun 2012, Halaman 1-7

Online di : http://ejournal-sl.undip.ac.id/index.php/maquares

\begin{tabular}{clcccccc}
\hline 6 & Thalassia hemprichii & 645 & 39,8 & 686 & 46,8 & 622 & 53,2 \\
7 & Syringodium isoetifolium & 17 & 1 & - & - & 70 & 5,9 \\
\hline Jumlah & 1.620 & 100 & 1.467 & 100 & 1.169 & 100 \\
\hline
\end{tabular}

Pada Tabel 2 menunjukkan kerapatan jenis lamun tertinggi di ketiga stasiun yaitu Thalassia hemprichii dan Cymodocea rotundata, sedangkan untuk jumlah total individu lamun pada stasiun 1,2 dan 3 yakni $1.620 \mathrm{ind} / 15 \mathrm{~m}^{2}$; $1.467 \mathrm{ind} / 15 \mathrm{~m}^{2}$ dan $1.169 \mathrm{ind} / 15 \mathrm{~m}^{2}$. Berdasarkan hasil penelitian yang dilakukan, di ketiga stasiun pengamatan jumlah dan jenis lamun yang ditemukan berbeda (tidak selalu sama), yakni jenis terbanyak ditemui pada stasiun 1 (zona alami) sebanyak tujuh jenis, sedangkan pada stasiun 2 (zona pemukiman) dan 3 (zona resort wisatawan) hanya dijumpai empat jenis lamun. Nilai kerapatan jenis tertinggi juga terdapat di stasiun 1 yakni 1.620 individu/ $15 \mathrm{~m}^{2}$. Hal ini dimungkinkan karena karakteristik substrat yang berbeda antar stasiun, sebaran pertumbuhan lamun yang tidak tersebar secara merata dan beberapa faktor lingkungan lainnya seperti kondisi lingkungan yang berbeda. Stasiun 1 (zona alami) kondisi lingkungannya masih alami dalam kondisi baik dan belum tercemar oleh aktivitas masyarakat maupun aktivitas wisata sehingga diduga lamun tumbuh baik disana, sedangkan pada stasiun 2 dan 3 (zona pemukiman dan resort) kondisi lingkungannya sudah dipengaruhi oleh berbagai kegiatan manusia (seperti adanya limbah/sampah, kegiatan nelayan setempat maupun untuk pariwisata) yang menjadikan kondisi perairan dan lingkungan sedikit terganggu sehingga mempengaruhi ekosistem lamun yang ada disana. Hal ini menunjukkan kerapatan jenis lamun akan semakin tinggi bila kondisi lingkungan perairan tempat lamun tumbuh dalam keadaan baik. Menurut Kiswara (2004), kerapatan jenis lamun di pengaruhi faktor tempat tumbuh dari lamun tersebut. Beberapa faktor yang mempengaruhi kerapatan jenis lamun di antaranya adalah kedalaman, kecerahan, arus air dan tipe substrat.

\section{Persentase Penutupan dan Frekuensi}

Hasil persentase penutupan jenis, penutupan komunitas dan frekuensi jenis tersaji pada Tabel 3, 4 dan 5. Tabel 3. Penutupan Jenis (Ci) dan Penutupan Relatif (RCi)

\begin{tabular}{llcccccc}
\hline \multirow{2}{*}{ No } & \multicolumn{1}{c}{ Jenis } & \multicolumn{2}{c}{$\mathrm{Stasiun} 1(\%)$} & \multicolumn{2}{c}{$\mathrm{Stasiun} 2(\%)$} & \multicolumn{2}{c}{$\mathrm{Stasiun} \mathrm{3( \% )}$} \\
\cline { 3 - 7 } & & $\mathrm{Ci}$ & $\mathrm{RCi}$ & $\mathrm{Ci}$ & $\mathrm{RCi}$ & $\mathrm{Ci}$ & $\mathrm{RCi}$ \\
\hline 1 & Cymodocea rotundata & 29,38 & 38,1 & 17,5 & 37 & 11,88 & 31 \\
2 & Cymodocea serrulata & 2,5 & 3,2 & 0,63 & 1,3 & - & - \\
3 & Enhalus acoroides & 10,83 & 14 & 5,42 & 11,4 & 3,34 & 8,7 \\
4 & Halodule uninervis & 0,66 & 0,8 & - & - & - & - \\
5 & Halophila ovalis & 0,83 & 1,1 & - & - & - & - \\
6 & Thalassia hemprichii & 32,29 & 42 & 23,75 & 50,2 & 20 & 52,2 \\
7 & Syringodium isoetifolium & 0,66 & 0,8 & - & - & 3,12 & 8,1 \\
\hline & Total & & 100 & & 100 & & 100 \\
\hline
\end{tabular}

Tabel 4. Penutupan Total Komunitas

\begin{tabular}{lccc}
\hline & Stasiun 1 & Stasiun 2 & Stasiun 3 \\
\hline Persentase penutupan & $68 \%$ & $59 \%$ & $48 \%$ \\
Substrat terbuka & $32 \%$ & $41 \%$ & $52 \%$ \\
\hline
\end{tabular}

Persentase penutupan total komunitas lamun di stasiun 1, 2 dan 3 secara berurutan yakni $68 \%$; 59\% dan $48 \%$. Berdasarkan Keputusan Menteri Negara Lingkungan Hidup No. 20 Tahun 2004 bahwa stasiun 1 (utara) masuk kedalam kondisi sehat (penutupan $\geq 60 \%$ ), sedangkan untuk stasiun 2 (timur) dan 3 (selatan) masuk dalam kategori kondisi kurang sehat (penutupan 30-59,9\%). Di lihat dari penutupan lamun yang ditemui, daerah yang telah terganggu aktivitas manusia memiliki persen penutupan paling kecil dan penutupan lamun akan semakin tinggi pada daerah yang alami. Hal ini disebabkan gangguan ekosistem yang diterima lamun akibat pembuangan limbah rumah tangga serta aktivitas masyarakat. Menurut Dahuri et al.(2004) komposisi jenis, luas tutupan dan sebaran lamun dapat dipengaruhi ketersediaan nutrient pada substrat yang tidak merata sehingga lamun hanya tumbuh pada titik tertentu.

Tabel 5. Frekuensi Jenis (Fi) dan Frekuensi Relatif (RFi)

\begin{tabular}{llcccccc}
\hline \multirow{2}{*}{ No } & \multirow{2}{*}{ Jenis } & \multicolumn{2}{c}{ Stasiun $1(\%)$} & \multicolumn{2}{c}{ Stasiun 2(\%) } & \multicolumn{2}{c}{ Stasiun 3 $(\%)$} \\
\cline { 3 - 7 } & & $\mathrm{Fi}$ & $\mathrm{RFi}$ & $\mathrm{Fi}$ & $\mathrm{RFi}$ & $\mathrm{Fi}$ & $\mathrm{RFi}$ \\
\hline 1 & Cymodocea rotundata & 0,93 & 31,3 & 0,86 & 32 & 0,73 & 31,5 \\
2 & Cymodocea serrulata & 0,06 & 2 & 0,06 & 2 & - & - \\
3 & Enhalus acoroides & 0,8 & 26,9 & 0,86 & 32 & 0,53 & 22,8 \\
4 & Halodule uninervis & 0,06 & 2 & - & - & - & - \\
5 & Halophila ovalis & 0,26 & 8,7 & - & - & - & - \\
6 & Thalassia hemprichii & 0,8 & 26,9 & 0,93 & 34 & 0,86 & 37,1 \\
7 & Syringodium isoetifolium & 0,06 & 2 & - & - & 0,2 & 8,6 \\
\hline
\end{tabular}

${ }^{*}$ Penulis Penanggung Jawab 
JOURNAL OF MANAGEMENT OF AQUATIC RESOURCES.

Volume, Nomor, Tahun 2012, Halaman 1-7

Online di : http://ejournal-s1.undip.ac.id/index.php/maquares

$\begin{array}{lllllll}\text { Jumlah } & 2,97 & 100 & 2,71 & 100 & 2,32 & 100\end{array}$

Frekuensi merupakan peluang suatu jenis ditemukan dalam titik contoh yang diamati (Brower et al., 1989). Cymodocea rotundata, Thalassia hemprichii dan Enhalus acoroides merupakan jenis yang dominan dijumpai pada sejumlah plotplot pengamatan.

Indeks Nilai Penting

INP ditentukan oleh jumlah frekuensi relatif, kerapatan relatif dan penutupan relatif. Tersaji pada Tabel 6. Tabel 6. Indeks Nilai Penting (INP)

\begin{tabular}{clccc}
\hline No. & \multicolumn{1}{c}{ Jenis } & $\begin{array}{c}\text { Stasiun } 1 \\
(\%)\end{array}$ & $\begin{array}{c}\text { Stasiun } 2 \\
(\%)\end{array}$ & $\begin{array}{c}\text { Stasiun } 3 \\
(\%)\end{array}$ \\
\hline 1 & Cymodocea rotundata & 105,8 & 105,3 & 96,3 \\
2 & Cymodocea serrulata & 7,8 & 5,1 & - \\
3 & Enhalus acoroides & 56,9 & 58,5 & 38,5 \\
4 & Halodule uninervis & 4,1 & - & - \\
5 & Halophila ovalis & 12,6 & - & - \\
6 & Thalassia hemprichii & 108,7 & 131 & 142,5 \\
7 & Syringodium isoetifolium & 3,8 & - & 22,6 \\
\hline & Total & $300 \%$ & $300 \%$ & $300 \%$ \\
\hline
\end{tabular}

INP digunakan untuk menghitung dan menduga secara keseluruhan dari peranan satu spesies di dalam suatu komunitas. Semakin tinggi nilai INP suatu spesies relatif terhadap spesies lainnya maka semakin tinggi peranan spesies tersebut pada komunitasnya (Brower et al., 1989). Thalassia hemprichii, Cymodocea rotundata dan Enhalus acoroides memiliki peranan yang lebih tinggi diantara keempat jenis lainnya dalam komunitasnya dilihat dari nilai INP per spesies.

\section{Sebaran Lamun (Indeks Morisita)}

Pola penyebaran lamun menggunakan Indeks Morisita dapat dilihat pada Tabel 7.

Tabel 7. Perhitungan Nilai Indeks Morisita

\begin{tabular}{llcccc}
\hline No. Jenis & & \multicolumn{3}{c}{ Stasiun } & Jumlah \\
\cline { 3 - 5 } & & $\mathrm{I}\left(\mathrm{ind} / 15 \mathrm{~m}^{2}\right)$ & $\mathrm{II}\left(\mathrm{ind} / 15 \mathrm{~m}^{2}\right)$ & $\mathrm{III}\left(\mathrm{ind} / 15 \mathrm{~m}^{2}\right)$ & \\
\hline 1 & Cymodocea rotundata & 439 & 533 & 395 & 1.517 \\
2 & Cymodocea serrulata & 260 & 26 & - & 69 \\
3 & Enhalus acoroides & 21 & 222 & 82 & 564 \\
4 & Halodule uninervis & 45 & - & - & 21 \\
5 & Halophila ovalis & 645 & 686 & - & 45 \\
6 & Thalassia hemprichii & 17 & - & 70 & 1.953 \\
7 & Syringodium isoetifolium & 1.620 & 1.467 & 1.169 & 4.256 \\
\hline & Jumlah $\left(\sum \mathrm{X}\right)$ & $\mathbf{1 , 0 1 4}$ & $\mathbf{0 , 4 7 5}$ & $\mathbf{0 , 3 0 2}$ & \\
\cline { 1 - 4 } & Indeks Morisita $(\mathrm{I} \partial)$ & \multicolumn{3}{c}{}
\end{tabular}

Pola sebaran lamun yang dihitung menggunakan rumus Indeks Morisita (Brower et al., 1989) yakni pada stasiun 1 hasil yang didapatkan 1,014 sehingga Id > 1 yang berarti pola sebaran mengelompok (cluster). Lain halnya dengan stasiun 2 dan stasiun 3 hasil yang didapatkan secara berurutan yaitu 0,475 dan 0,302, Id $<1$ yang berarti pola sebaran seragam (uniform). Pada stasiun 2 dan 3 menunjukkan pola sebaran lamun seragam, menurut Crawley (1986) pola sebaran seragam artinya jarak antara individu dengan individu lain pada jenis yang sama dalam satu wilayah adalah sama atau hampir sama. Menurut Azkab (2006), untuk perairan tropis seperti Indonesia padang lamun lebih dominan tumbuh dengan koloni yang terdiri dari beberapa jenis (mix species) pada suatu kawasan tertentu. Berbeda dengan kawasan temperate atau daerah dingin yang kebanyakan di dominasi satu jenis lamun (single species). Penyebaran lamun memang sangat bervariasi tergantung pada topografi pantai dan pola pasang surut.

\section{Korelasi antara Kerapatan Lamun dengan Persentase Substrat}

Uji korelasi menggunakan bantuan software Microsoft Excel 2007. Variabel yang diuji yaitu nilai total kerapatan lamun di tiga stasiun dengan persentase substrat (gravel/sand/silt). Setelah diuji nilai korelasi positif diperoleh dari variabel kerapatan lamun dengan persentase kandungan gravel, sedangkan untuk sand dan silt menunjukkan korelasi negatif.

${ }^{*}$ Penulis Penanggung Jawab 


\section{JOURNAL OF MANAGEMENT OF AQUATIC RESOURCES. \\ Volume, Nomor, Tahun 2012, Halaman 1-7 \\ Online di : http://ejournal-sl.undip.ac.id/index.php/maquares}

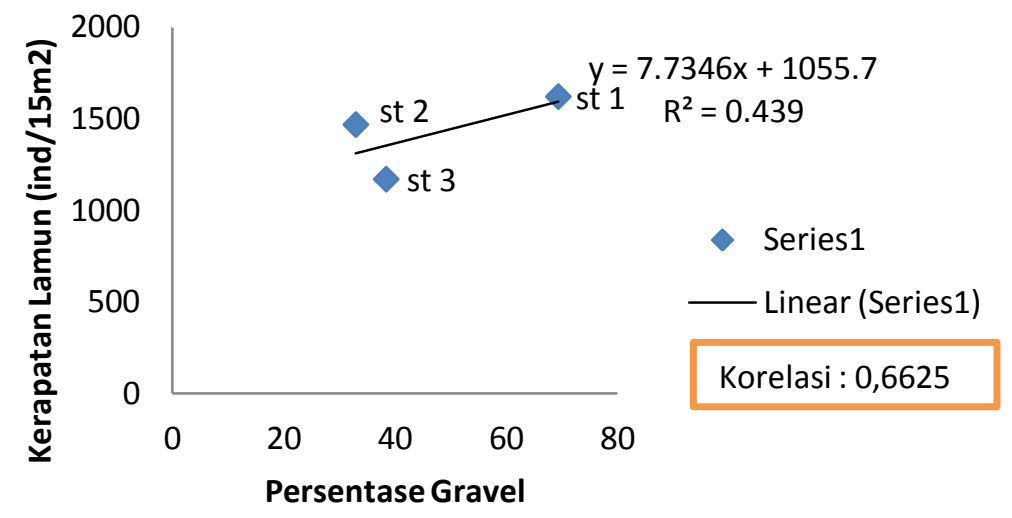

Gambar 1. Grafik Korelasi Kerapatan Lamun dengan Substrat Gravel

Nilai korelasi antara kerapatan lamun dengan kandungan gravel seperti pada Gambar 2 diperoleh nilai 0,6625 yang berarti hubungan diantara keduanya cukup erat dan berhubungan searah, artinya semakin besar variabel independent (gravel) maka akan semakin besar pula variabel dependent (kerapatan lamun). Nilai koefisien determinasi $\left(\mathrm{R}^{2}\right)$ yang diperoleh $0,439(43,9 \%)$, koefisien determinasi menunjukkan bahwa hampir 43-44\% kerapatan lamun dipengaruhi oleh persentase gravel dan $56,1 \%$ oleh pengaruh luar.

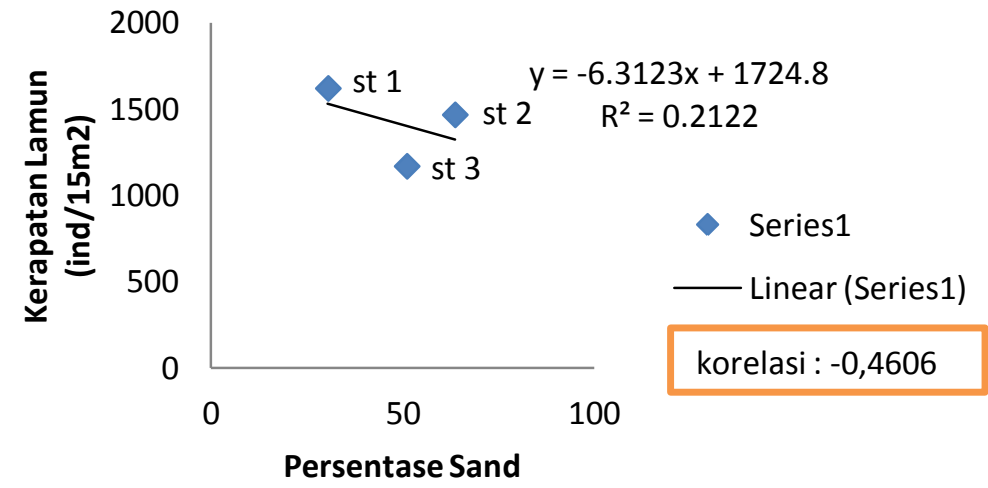

Gambar 2. Grafik Korelasi Kerapatan Lamun dengan Substrat Sand

Nilai korelasi antara kerapatan lamun dengan kandungan pasir (sand) seperti pada Gambar 2 diperoleh nilai 0,4606. Korelasi negatif menunjukkan ada hubungan diantara keduanya namun secara berlawanan arah, artinya semakin besar variabel independent (sand) maka akan semakin kecil pula dependent (kerapatan lamun). Nilai determinasi $\left(\mathrm{R}^{2}\right)$ yang diperoleh 0,212 , artinya dipengaruhi faktor dalam senilai $21,2 \%$ dan $78,8 \%$ faktor luar.

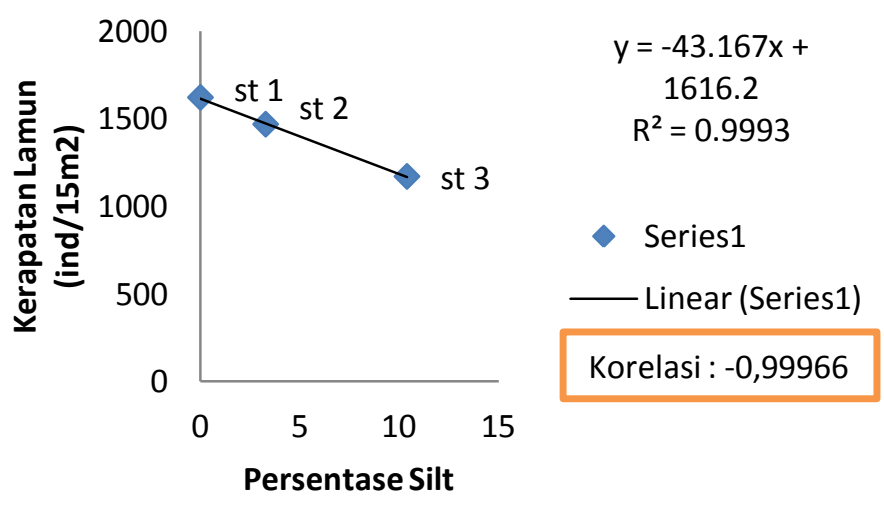

Gambar 3. Grafik Korelasi Kerapatan Lamun dengan Substrat Silt 


\section{JOURNAL OF MANAGEMENT OF AQUATIC RESOURCES. \\ Volume, Nomor, Tahun 2012, Halaman 1-7 \\ Online di : http://ejournal-s1.undip.ac.id/index.php/maquares}

Nilai korelasi antara kerapatan lamun dengan kandungan silt seperti pada Gambar 3 diperoleh nilai -0,99966 yang berarti semakin besar variabel independent (kandungan silt) maka akan semakin kecil pula variabel dependent (kerapatan lamun), dan hubungannya berlawanan arah. Namun, koefisien determinasi sangat tinggi yaitu $99,9 \%$ artinya kerapatan lamun sangat dipengaruhi oleh kandungan silt (lumpur). Karena substrat berpengaruh kecil terhadap kerapatan lamun, hal ini diduga dapat dimungkinkan oleh beberapa faktor luar. Faktor luar disini diduga dari faktor lingkungan lain, seperti nilai pH, arus, temperatur atau salinitas perairan tersebut. Menurut Nybakken (1992), penyebaran horizontal lamun dipengaruhi oleh karakteristik substrat dan kondisi gerakan air (arus perairan).

\section{Parameter Fisika dan Kimia}

Hasil pengukuran nilai parameter fisika dan kimia perairan dapat dilihat pada Tabel 8.

Tabel 8. Karakteristik Parameter Fisika dan Kimia

\begin{tabular}{clccc}
\hline No. & \multicolumn{1}{c}{ Parameter } & Stasiun 1 & Stasiun 2 & Stasiun 3 \\
\hline & Fisika & 32 & & \\
1. & Suhu Air $\left({ }^{\circ} \mathrm{C}\right)$ & 28 & 30 & 32 \\
2. & Suhu Udara $\left({ }^{\circ} \mathrm{C}\right)$ & 0,044 & 27 & 29 \\
3. & Kecepatan Arus $(\mathrm{m} / \mathrm{s})$ & $20-60$ & $27-75$ & 0,061 \\
4. & Kedalaman $(\mathrm{cm})$ & & & $25-60$ \\
& Kimia & 8 & 6 & 7 \\
5. & pH & 33 & 31 & 31 \\
6. & Salinitas $(\%)$ & & & \\
\hline
\end{tabular}

Suhu perairan di stasiun 2 yakni $30^{\circ} \mathrm{C}$, dimana pada saat sampling cuaca sedikit mendung dan usai hujan, sedangkan suhu tertinggi terdapat di stasiun 1 dan 3 yaitu $32{ }^{\circ} \mathrm{C}$ karena pada saat sampling cuaca cerah. Menurut Hutomo (1985) suhu yang normal untuk pertumbuhan lamun di perairan tropis berkisar antara $24{ }^{\circ} \mathrm{C}-35{ }^{\circ} \mathrm{C}$. Kecepatan arus yang terukur di tiga stasiun berkisar antara $0,044-0,238 \mathrm{~m} / \mathrm{s}$. Arus pada stasiun 2 relatif sedikit cepat dibandingkan dengan stasiun 1 dan 3 yang relatif lebih tenang, hal ini dimungkinkan karena faktor cuaca pada saat sampling. Menurut Dahuri et al.(2004) pergerakan arus berpengaruh terhadap pertumbuhan lamun yang terkait dengan suplai unsur hara dan persedian gas-gas terlarut yang dibutuhkan oleh lamun. Pengaruh pasang surut serta struktur substrat dapat mempengaruhi zonasi sebagian jenis lamun dan pertumbuhannya.

Kisaran nilai salinitas di Pulau Pramuka berkisar antara 31 - 33\%. Salinitas terendah terdapat di stasiun 2 dan 3. Menurut Nybakken (1992) lamun hidup pada toleransi salinitas optimum $20-35 \%$. Nilai derajat keasaman (pH) di lokasi pengamatan berturut-turut sekitar $6-8$. $\mathrm{pH}$ terendah di stasiun 2 bernilai 6 , hal ini dimungkinkan pengaruh dari faktor cuaca dimana pada saat pengamatan kondisi cuaca mendung sampai hujan yang mengakibatkan $\mathrm{pH}$ perairan menjadi asam. $\mathrm{pH}$ tertinggi di stasiun I dengan $\mathrm{pH} 8$, sedangkan $\mathrm{pH}$ normal berada pada stasiun 3 . Hal ini dapat disebabkan karena pada stasiun 1 kandungan substrat gravel cukup tinggi, gravel yang terdiri dari butiran komposisi pecahan karang mati, cangkang biota dan sedikit pasir menyebabkan perairan lebih basa, karena pecahan karang yang telah mati mengandung zat kapur yang bersifat basa sehingga dapat mempengaruhi $\mathrm{pH}$ perairan.

\section{Karakteristik Substrat}

Berdasarkan hasil analisa substrat yang dilakukan di Laboratorium Mekanika Tanah, Fakultas Teknik Universitas Diponegoro didapatkan karakteristik substrat pada ketiga stasiun yakni pada Tabel 9 dibawah ini.

Tabel 9. Karakteristik Substrat

\begin{tabular}{lccc}
\hline \multicolumn{1}{c}{ Tipe } & Stasiun 1 & Stasiun 2 & Stasiun 3 \\
\hline Gravel (Batu/Pecahan karang) & $69,40 \%$ & $32,97 \%$ & $38,43 \%$ \\
Sand (Pasir) & $30,58 \%$ & $63,73 \%$ & $51,16 \%$ \\
Silt (Lanau/Endapan lumpur) & $0,02 \%$ & $3,30 \%$ & $10,41 \%$ \\
Clay (Lempung) & $0,00 \%$ & $0,00 \%$ & $0,00 \%$ \\
\hline
\end{tabular}

Tipe substrat pada ekosistem padang lamun di Pulau Pramuka sebagian besar terdiri dari gravel dan sand (pasir). Secara umum pada stasiun 2 dan 3 mempunyai komposisi pasir jauh lebih besar yaitu sekitar 51,16\% - 63,73\% dibandingkan dengan komposisi gravel, silt dan clay. Stasiun 1 komposisi substrat sebagian besar didominasi oleh gravel dibandingkan sand. Komposisi clay tidak ada (0\%), sedangkan kadar silt di stasiun 1, 2 dan 3 berturut-turut yakni $0,02 \%, 3,30 \%$ dan $10,41 \%$. Klasifikasi tipe substrat seperti berbatu, berpasir, pasir berlumpur, dan lumpur berpasir didasari oleh komposisi partikel yang terkandung dalam substrat (Irfania, 2009). Menurut Erftemeijer (1993) dalam Dahuri et al. (2004), lamun tumbuh subur terutama di daerah pasang surut terbuka serta perairan pantai yang dasarnya berupa lumpur, pasir, kerikil, dan patahan dengan karang mati. Kebutuhan substrat yang paling utama bagi pengembangan padang lamun adalah kedalaman sedimen yang cukup. Peranan kedalaman substrat dalam stabilitas 


\section{JOURNAL OF MANAGEMENT OF AQUATIC RESOURCES. \\ Volume, Nomor, Tahun 2012, Halaman 1-7 \\ Online di : http://ejournal-s1.undip.ac.id/index.php/maquares}

sedimen mencakup 2 hal, yaitu: (1) pelindung tanaman dari arus air laut, (2) tempat pengolahan dan pemasok nutrien (Kiswara, 2000).

\section{Kesimpulan}

Berdasarkan hasil penelitian yang telah dilakukan maka dapat diambil kesimpulan sebagai berikut:

1. Dari 7 jenis yang ditemukan yaitu Cymodocea rotundata, Cymodocea serrulata, Enhalus acoroides, Halodule uninervis, Halophila ovalis, Thalassia hemprichii dan Syringodium isoetifolium. Stasiun 1 (zona alami) memiliki 7 jenis, sedangkan stasiun 2 (zona pemukiman) dan 3 (zona resort wisatawan) hanya 4 jenis. Jenis yang mendominasi di ketiga stasiun adalah Thalassia hemprichii dan Cymodocea rotundata.

2. Dilihat dari nilai kelimpahan dan penutupan lamun tertinggi diperoleh pada stasiun 1. Kerapatan lamun yang tertinggi diperoleh di stasiun 1 yakni total 1.620 individu/15m². Berdasarkan Keputusan Menteri Negara Lingkungan Hidup No. 20 Tahun 2004 bahwa stasiun 1 (zona alami) dengan persentase penutupan 68\% masuk kedalam kondisi sehat (penutupan $\geq 60 \%$ ), sedangkan untuk stasiun 2 (zona pemukiman) dan 3 (zona resort) dengan persentase masing-masing 59\% dan 48\% masuk dalam kategori kondisi kurang sehat (penutupan 30-59,9\%). Pola sebaran (distribusi) lamun pada stasiun 1, 2 dan 3 yakni 1,014; 0,475; 0,302 yang berarti pola sebaran mengelompok (cluster) pada stasiun 1 dan seragam (uniform) untuk stasiun 2 dan 3.

\section{Daftar Pustaka}

Azkab MH. 2006. Ada apa dengan lamun. Majalah Semi Polpuler Oseana 31(3):45-55

Brower JE, Zar JH \& Ende CNV. 1989. Field and laboratory method for general ecology fourth edition. McGraw-Hill Publication. Boston, USA. xi $+273 p$.

Crawley, MJ. 1986. The Structure of Plant Communities in Plant Ecology. Crawley, MJ (Ed). Blackwell Scientific Publication, Oxford, London.

Dahuri, R., J. Rais, S. P. Ginting dan M. J. Sitepu. 2004. Pengelolaan Sumberdaya Wilayah Pesisir dan Lautan secara Terpadu. Edisi Revisi. Pradnya Paramita. Jakarta.

Gulo, W. 2005. Metodologi Penelitian. Grasindo. Jakarta.

Hutomo, M. 1985. telaah Ekologik Komunitas Ikan pada Padang Lamun (Seagrass, Anthophyta) di Perairan Teluk Banten. Disertasi. Fakultas Pascasarjana, Institut Pertanian Bogor. Bogor.

Irfania, Rohanipah. 2009. Pengukuran Nilai Acoustic Backscattering Strength Berbagai Tipe Substrat Dasar Perairan Arafura Dengan Instrumen Simrad Ek60. Institut Pertanian Bogor. Bogor.

Keputusan Menteri Lingkungan Hidup Nomor 20 Tahun 2004. Kriteria Baku Kerusakan dan Pedoman Penentuan Status Padang Lamun. Deputi MENLH Bidang Kebijakan dan Kelembagaan Lingkungan Hidup.

Kiswara. 2000. Struktur komunitas padang lamun perairan Indonesia.p. 54-61. In: Inventarisasi dan evaluasi potensi laut-pesisir, geologi, kimia, biologi, dan ekologi. Lembaga Ilmu Pengetahuan Indonesia. Jakarta.

2004. Kondisi padang lamun (seagrass) di perairan Teluk Banten 1998-2001. Lembaga Penelitaian Oseanografi, Lembaga Ilmu Pengetahuan Indonesia. Jakarta.

Nontji, A. 2002. Laut Nusantara. Djambatan. Jakarta.

Nybakken. J. W. 1992. Biologi Laut. Suatu Pendekatan Ekologis. PT Gramedia. Jakarta.

WESTPAC. 2010. Field Guide to the Identification of East Asian, with Financial Support From The Japanese Funds-inTrust for UNESCO. 